\title{
6 \\ Can Foreign Firms Promote Local Production of Pharmaceuticals in Africa?
}

Sudip Chaudhuri

\section{Introduction}

African countries, particularly the smaller ones, suffer from various disadvantages that prevent local producers from serving a substantial proportion of their domestic markets for pharmaceuticals. How to take care of these disadvantages to promote local production and to reduce dependence on imports is an important political and economic issue in Africa today. Most of the countries with developed industries have used foreign investments and technology in the process of their development. Is a similar trend likely in Africa? Are foreign companies likely to invest there to undertake manufacturing of pharmaceuticals? Can they be induced to do so? The objective of this chapter is to understand the prospects for foreign direct investment (FDI) in the pharmaceutical industry in Sub-Saharan Africa, particularly in smaller countries such as Ghana.

The foreign firms which are active in Africa can be broadly classified between the multinational corporations (MNCs) and the Indian generic companies. These two types of firms are quite different in terms of background and behaviour, and in the next section some of these differences are briefly outlined. The environment for pharmaceutical production and manufacturing is changing quite rapidly, both in Africa and abroad, and that is having an impact on the behaviour of both the MNCs and the Indian companies. The chapter first focuses on the MNCs and discusses the implications for the pharmaceutical markets in Africa. It then focuses on the Indian companies. We will see in the discussion that follows that on their own initiative, Indian companies may not be very 
keen to undertake investments for manufacturing in Africa. But given a conducive environment, they may not be averse to initiating manufacturing in Africa on a greater scale. The final section of the chapter takes up the case of Ghana, a relatively small African country. After a brief introduction to the structure of pharmaceutical market and industry in Ghana, the chapter analyses some policies which may be undertaken to promote local production, particularly in order to induce foreign firms to invest in Ghana.

\section{MNCs, generics companies and the international pharmaceutical industry}

Traditionally, pharmaceutical companies are classified between a small number of big MNCs that do research and development (R\&D) for new drugs and aim to get these patented, and a large number of smaller generics companies that manufacture products that are not patented or products for which patents have expired. The MNCs are exceptionally large in size. The head offices are located in developed countries, mainly in the US, the UK, Switzerland, France, and Germany. They operate all over the world. The largest pharmaceutical MNC, Novartis (headquarters: Basel, Switzerland) reported US $\$ 46$ billion in pharmaceutical sales in 2013. Each of the other top five MNCs - Pfizer (US), Roche (Switzerland), Sanofi (France), Merck (US) and GlaxoSmithKline (UK) - individually had sales worth more than the entire pharmaceutical market of the Middle East and Africa in 2013. ${ }^{1}$

The patent system and marketing power are at the root of the worldwide dominance of the MNCs. Naturally, for the products patented by the MNCs, they enjoy a monopoly status. They also use an elaborate marketing infrastructure to maintain dominant market shares even after patents expire. Even when the product is protected through patents, the MNCs promote their drugs under brand names, that is, through trademarks, rather than under generic names, which are commonly used in scientific literature. They continue using these brand names and try to take advantage of continuing brand loyalty when generic companies enter the market after the expiry of patents.

Traditionally MNCs have relied for their growth on patented drugs, and have focussed mainly on the large developed country markets. The largest pharmaceutical market is in US (US\$343 billion), and this together with Western Europe (US\$241.4 billion) and Japan (US\$129.5 billion) accounted for about two-thirds of the global pharmaceutical market of US\$1,052.1 billion in 2012 (BMI Espicom, 2013). 
Like most other countries in the world, India after independence initially recognized product patent protection in pharmaceuticals, and the MNCs dominated the Indian market too. However, the abolition of product patents in 1972 eliminated the monopoly status that the MNCs enjoyed until then. Indian firms started manufacturing and marketing the latest drugs and were able to dislodge the MNCs from their position of dominance in the domestic market. India became self-reliant in drugs. The country furthermore emerged as a major player in the global pharmaceutical industry, receiving worldwide recognition as a low-cost producer of high-quality drugs. India now supplies medicines not only to other developing countries such as those in Africa but also to developed countries such as the United States.

The Indian pharmaceutical industry is highly heterogeneous. Most of the firms are small in size and operate only in the domestic market or in other developing countries. But some of the companies are large and not only compete with these small firms in these markets but also are active in regulated markets in developed countries. Two companies from India - Sun Pharmaceuticals (rank 48) and Ranbaxy (rank 50) - are among the 50 largest pharmaceutical companies in the world. ${ }^{2}$ With the acquisition of Ranbaxy in 2014, Sun Pharmaceuticals will make a significant jump in the rankings. Other major Indian companies include Dr Reddys Laboratories, Cipla, Lupin, Glenmark and Cadila Healthcare. The larger Indian companies not only manufacture drugs in India and export these to different parts of the world. They have also started acquiring companies abroad to expand their manufacturing and marketing operations.

\section{The changing marketing strategy of MNCs in Africa}

Due to colonial or other links, some of the MNCs, for example GlaxoSmithKline (Glaxo as the firm then was known), had offices in some African countries. But as the MNCs started focusing more on the larger and more lucrative developed country markets, the African markets, especially in small countries, became less and less important for them and they started closing down their offices. Of course, their products were still available, but these imports were managed by their agents - local importers/distributors.

In recent years, however, the MNCs are returning to Africa and are focusing more on the subcontinent. Both push and pull factors are in operation. The most important push factor is that developed country markets have become less attractive, and the main pull factor is the 
better growth prospects in Africa (Mckinsey and Company, 2013; Tempest, 2011).

The cost of developing new drugs has gone up, but the introduction of new patented drugs in the market has slowed down. Earlier, as mentioned above, because of the steady flow of new patented drugs, the MNCs focussed mainly on the large markets for patented medicines in high-income countries. But in view of the declining productivity of $\mathrm{R} \& \mathrm{D}, \mathrm{MNCs}$ can no longer afford to ignore the generics markets. Their turn to generics markets includes not only the patent-expired markets in the high-income countries but also the generics markets in emerging economies. The centres of economic activity are changing, with most of the growth expected to come from emerging markets (Mckinsey and Company, 2013).

Among emerging markets, Africa is still relatively small. The combined size of the market of the top ten African countries is about US $\$ 14$ billion, compared to US\$343 billion in the US and US\$129 billion in Japan (Table 6.1). However, the future growth is expected to take place in emerging countries, including in Africa, rather than in the developed countries. It has been estimated that between 2012 and 2018, major developed country pharmaceutical markets will remain stagnant (as in Japan and the UK), increase marginally (as in the US), decline marginally (as in Germany and France) and decline significantly (as in Italy and Spain). In contrast, the top ten African countries are expected to grow at $11 \%$ annually (Table 6.1). Quite understandably, therefore, while preparing their strategies for future, the MNCs are focusing more on the emerging countries, including in Africa.

The major drivers of growth in pharmaceutical markets in Africa have included increased disease burdens, particularly HIV/AIDS. The private markets have been expanded by developments in health insurance schemes, and some countries' health systems have seen large investments in public health. Political stability and rapid economic development, improving business climate, a maturing regulatory environment and increased confidence in generic products have all also contributed to market expansion (African Union and UNIDO, 2012; Mckinsey and Company, 2013).

The changes are having a variety of different impacts on the behaviour of the MNCs in Africa. The MNCs are no longer relying only on their agents. They have started opening offices and staffing these with their own employees. Marketing expenses for brand promotion have risen. To push up their sales they have also started offering credit facilities. Another notable development is that the MNCs are toning up their 
Table 6.1 Anticipated trends in global pharmaceutical markets

\begin{tabular}{|c|c|c|c|}
\hline Country & $\begin{array}{c}\text { Market size } \\
2012 \\
\text { (US\$ billion) }\end{array}$ & $\begin{array}{c}\text { Estimated } \\
\text { market size } \\
2018 \\
\text { (US\$ billion) }\end{array}$ & $\begin{array}{c}\text { Anticipated } \\
\text { annual growth } \\
\text { rate*, } \\
\text { 2012-2018 (\%) }\end{array}$ \\
\hline \multicolumn{4}{|c|}{ Emerging markets } \\
\hline China & 82 & 164 & 12 \\
\hline Russia & 22 & 39 & 10 \\
\hline India & 16 & 28 & 10 \\
\hline Brazil & 27 & 39 & 7 \\
\hline Africa** & 14 & 26 & 11 \\
\hline \multicolumn{4}{|c|}{ Developed markets } \\
\hline US & 343 & 360 & 1 \\
\hline Japan & 129 & 129 & 0 \\
\hline Germany & 49 & 47 & -1 \\
\hline France & 43 & 41 & -1 \\
\hline UK & 38 & 38 & 0 \\
\hline Canada & 26 & 25 & -1 \\
\hline Italy & 28 & 22 & -4 \\
\hline Spain & 23 & 16 & -6 \\
\hline
\end{tabular}

Note: * Compound annual rate of growth

** South Africa, Algeria, Egypt, Morocco, Tunisia, Sudan, Nigeria, Libya, Ivory Coast and Kenya.

Source: Mckinsey and Company, 2013.

distribution networks. They have started using the services of specialized supply chain organizations such as Imperial Health Sciences. The latter has operations in South Africa, Kenya, Ghana, Nigeria and Malawi, where medicines are received, stored and distributed in countries across Africa.

Perhaps the most significant development of all is that MNCs have started introducing new brands to compete in the generic markets. As mentioned above, when MNCs market new patented drugs, they sell these in brand names and continue to do so even after the patents expire. The patented drugs in monopoly markets are high priced. For patent-expired products too, the MNCs participate in the higher end of the market that has more limited competition. Even after the patents expire, the firms typically continue to use the same brands and continue to charge a very high price.

This strategy on the part of the MNCs has, in fact, helped the Indian generic companies. The large Indian companies typically adopt the strategy of charging a price lower than that of the MNCs to enter and 
grow market share in the patent-expired products. Armed with lower prices and active brand promotion, Indian companies such as Cipla, Ranbaxy, Sun Pharmaceuticals, Cadila and Glenmark have been able to dominate the markets in many products.

Particularly for Sub-Saharan African countries, India is the predominant supplier. In Tanzania, for example, the Indian generics company Cipla was the second-largest company in the retail market in 2010 with a market share of $16 \%$, next only to the local firm, Shelys (21\% market share), and ahead of MNCs such as Novartis (10\%) and GSK (6\%). Among the other notable Indian participants are companies such as Ranbaxy (8\%), Sun Pharmaceuticals, Unichem Laboratories, Cadila Glenmark and Ajanta Pharma (Frost and Sullivan, 2010: 151; 2012: 81-83). As in most African countries, local firms in Tanzania manufacture a relatively simple list of formulations such as simple antibiotics, cough and cold preparations, analgesics antipyretics, sedatives, nutraceuticals, anthelmintics and anti-malarials (see Chapter 3; Chaudhuri et al., 2010). For technologically more sophisticated formulations, the competition is mainly between the MNCs and the Indian companies.

The MNCs are now increasingly trying to make their presence felt in these generic markets. They are reluctant to dilute their innovator brand by lowering the price to compete against generic products. There is a brand loyalty associated with innovator products and there is a priceinsensitive market segment where MNCs continue to sell despite high prices and despite the availability of cheaper generic products. To enlarge their market, the MNCs are introducing new brands and selling these at prices significantly lower than their innovator brands. The dual-brand strategy enables them to be present not only in the price-insensitive segment of the market but also in the price-sensitive segment.

The most active MNC in this game is GSK. The innovator brand for their anthelmintic drug, albendazole, is Zentel. They have introduced a new brand for the same product, named Alzental. Another example is the antibiotic amoxicillin/clavulanate. The GSK innovator brand is Augmentin. They also sell the same product in the brand name Clavulin to compete against similar-sounding generic brands such as, for example, Clavam of India's generics company Alkem. These MNC generic brands are priced significantly below the innovator price, often $50 \%$ or less. These are still priced above the brands of generic companies. But with the price differential much smaller and their better reputation, the MNCs hope to prevent the slide in their sales in the generics markets.

Now that they have started competing on prices, the matter of costs has become important. Another important trend observed is that the 
MNCs are trying to get their generic products manufactured in cheaper locations. The Ghanaian company LaGray has entered into an agreement with Sandoz, the generic arm of Novartis. The former will manufacture products to be marketed in their brand names by the latter. India offers an even cheaper location. MNCs such as GSK, AstraZeneca and Abbott have entered into supply agreements with Indian companies such as Dr Reddys, Aurobindo, Cadila Healthcare and Torrent. Dr Reddys, for example, will supply about 100 branded formulations to GSK for marketing in different emerging markets including in Africa. These deals enable the MNCs to get access to low-cost reliable products without undergoing the lengthy process of getting regulatory approvals in different markets and without incurring any capital expenditure for setting up manufacturing plants. The Indian companies gain by having access to the formidable marketing resources of the MNCs (Chaudhuri, 2012).

However, what these trends indicate is that although MNCs are targeting African markets, they are unlikely to make any significant investments to manufacture drugs in Africa, at least not in the near future.

\section{Indian generic companies in the African market}

European countries, mainly France, Germany and Switzerland, are the most important suppliers for some relatively large North African countries such as Algeria, Morocco and Egypt (UNCOMTRADE). But for Sub-Saharan Africa, India is the predominant supplier of medicines. As Table 6.2 shows, in 2012 India contributed more than 50\% of the formulations imports in Uganda and Mozambique and more than $40 \%$ in Nigeria, Ghana and Rwanda. Its share was also substantial in countries such as Ethiopia, Tanzania and Zimbabwe. If we could exclude the imports of high-priced patented medicines and focus only on generics, India's contribution to Africa would be much larger than Table 6.2 suggests. Where drugs are purchased from multiple sources, as for example for ARVs, India has turned out to be the dominant supplier, accounting for more than two-thirds of Africa's imports (Chaudhuri, 2008).

Indian generic companies exporting medicines to Africa can be classified into two broad categories: those which are active also in the regulated markets in developed countries such as the United States, and those which are not yet present in these markets. The larger and more reputed companies belong to the first category. These more dynamic Indian 
Table 6.2 Indian share of pharmaceutical formulations imports into Africa, 2012

\begin{tabular}{lrc}
\hline Country & $\begin{array}{c}\text { Total imports, } \\
\text { US\$ million }\end{array}$ & $\begin{array}{c}\text { Imports from } \\
\text { India (\%) }\end{array}$ \\
\hline Uganda & 204 & 57.6 \\
Mozambique & 50 & 52.6 \\
Nigeria & 263 & 43.7 \\
Ghana & 126 & 42.7 \\
Rwanda & 55 & 40.4 \\
Ethiopia & 154 & 39.3 \\
United Rep. of Tanzania & 161 & 36.8 \\
Zimbabwe & 170 & 36.6 \\
Mauritius & 103 & 34.7 \\
Burundi & 42 & 33.3 \\
Cameroon & 168 & 25.0 \\
Botswana & 124 & 23.1 \\
Niger & 44 & 21.3 \\
Côte d'Ivoire & 259 & 19.1 \\
Madagascar & 49 & 18.9 \\
South Africa & 1,890 & 15.9 \\
Namibia & 142 & 13.1 \\
Mauritania & 15 & 10.4 \\
Togo & 68 & 6.2 \\
Senegal & 167 & 4.5 \\
Mali & 142 & 4.1 \\
Morocco & 360 & 3.6 \\
Algeria & 1,879 & 2.6 \\
Cabo Verde & 8 & 1.3 \\
Egypt & 1,498 & 0.5 \\
Total (25 countries) & 8,139 & 13.7 \\
\hline & & \\
\hline & &
\end{tabular}

Source: Calculated from UNCOMTRADE database (http://comtrade.un.org).

generic companies have been more interested in the patent-expired markets in high-income countries such as the US and in Europe because of the larger markets and better prices realized. Prices achieved are higher in these markets because regulatory requirements to enter these markets are stricter and so entry is more difficult. The Indian companies active in the African markets also primarily target the markets where entry barriers are higher and hence competition is less strong. These companies promote their products through brands and their main competitors are the MNCs (and also generics companies from other countries). As mentioned above, these companies often try to enter and grow in these markets by charging a price lower than that of the innovator MNC. The 
smaller Indian companies are more active in over-the-counter medicines and in markets for simple products where they compete mainly against the local manufacturers and other smaller generic companies.

\section{The changing composition of Indian companies}

The composition of Indian generic companies is however changing in Africa. With improvements in the regulatory environment in Africa, the not so quality-conscious Indian companies are increasingly finding it difficult to operate there. Allegations have been made from time to time that some Indian companies have taken advantage of the regulatory environment in India and in Africa to export poor-quality drugs. In fact, it has been a very common complaint in Africa that India has not been taking initiatives to regulate the quality of drugs exported. This is now changing. Due to the efforts of the government in India and also some steps taken in some African countries, the quality standards have improved. Most African countries, for example, do not permit imports into their countries from India without a Certificate of Pharmaceutical Product (COPP). This is given by the drug control administration in India to units that qualify for the WHO-GMP standard. This standard is stricter than Schedule $\mathrm{M}$, the Indian version of GMP, and hence exporters are required to satisfy higher standards than in the domestic market.

Like the MNCs, the more serious Indian players are also getting more involved in Africa. Here too both push and pull factors are in operation. An important push factor arises from the fact that earlier expectations of huge gains in the patent-expired markets in large markets such as in the United States have not materialized. Those markets have turned out to be very competitive, despite some value-added market segments where competition can be limited and where gains are still substantial. ${ }^{3}$ However, with the declining R\&D productivity and a reduced flow of new patented drugs in the market, the MNCs are aggressively trying to make the entry of generic companies more difficult in these markets.

The better regulatory environment in Africa has improved the attractiveness of the market for the larger Indian companies and is acting as an important pull factor there. Perhaps more important is the anticipated future growth in the pharmaceutical market in Africa. The African market is still relatively small for Indian companies. Africa accounts for about $15 \%$ of India's exports (Table 6.3). But Africa is an expanding market for India. The growth of India's pharmaceutical exports has been quite spectacular, and Africa has been able to increase its share from about $10 \%$ in $1994-95$ to $15 \%$ in 2011-12. The growth of the African market has in fact been faster than all other regions except America 
Table 6.3 India's Pharmaceutical exports

\begin{tabular}{lcccc}
\hline & $\mathbf{1 9 9 4 - 9 5}$ & $\mathbf{1 9 9 4 - 9 5}$ & $\mathbf{2 0 1 1 - 1 2}$ & $\mathbf{2 0 1 1 - 1 2}$ \\
\cline { 2 - 5 } & (Rs million) & $\mathbf{( \% )}$ & (Rs million) & $\mathbf{( \% )}$ \\
\hline Europe & 10,663 & 42.4 & $90,964.35$ & 29.6 \\
America & 3,661 & 14.6 & $90,147.29$ & 29.3 \\
Asia & 7,941 & 31.6 & $77,886.87$ & 25.3 \\
Africa & 2,676 & 10.7 & $45,280.45$ & 14.7 \\
Oceania & 182 & 0.7 & $2,949.168$ & 1.0 \\
Others & 0 & 0 & 368.29 & 0.1 \\
Total & 25,123 & 100 & $307,596.4$ & 100.0 \\
\hline
\end{tabular}

Source: India's Directorate General of Commercial Intelligence and Statistics (DGCI\&S) trade data, accessed from the 'India Trades' database of the Centre for Monitoring Indian Economy.

(Table 6.3). In 1994-95, just Nigeria and Kenya accounted for about $50 \%$ of India's exports to Africa, and the share of top five countries was nearly three-quarters of the total. However India's exports now are more diversified. Among the countries which are relatively more important are Ghana, Benin, Sudan, Angola, Malawi and Cameroon. ${ }^{4}$

\section{Are Indian companies likely to invest in manufacturing in Africa?}

It is clear that Indian companies will continue to play a very active role in the African markets. Indeed, because of the factors mentioned above, they are likely to expand their operations there. Some Indian companies have already been actively involved in foreign direct investments (FDI) in Africa. Notable examples are Cadila in Ethiopia, Cipla in Uganda and South Africa and Ranbaxy in Nigeria. Other Indian companies too may be involved in the future in setting up manufacturing plants in Africa. But are Indian companies in general likely to be involved in any significant scale in investing in Africa? R Modi, chief of the Indian company Cadila, mentioned during his presentation at the African Pharmaceutical Summit in Hammamet, Tunisia, on 23-24 September 2013 that profit has not been the main motivation for Cadila's investments in Ethiopia. It is possible that beyond narrow financial reasons, some Indian companies will invest in Africa. But if Africa is to benefit in any significant way from Indian companies to further develop the industry there, what is required is more systematic investments. Unless Indian companies find Africa commercially attractive, it will be difficult to sustain such investments. 
Unless the policy environment changes in Africa, the indications are that Indian companies in general will continue to find exporting a better option than investing in Africa. The main reasons are the following.

Perhaps most importantly, Indian companies essentially face a free trade regime in Africa. Some countries impose tariffs on imports of finished formulations. Some countries have a restricted list, as in Ghana, as discussed below. But in general, imports are not otherwise controlled or prohibited. This implies that from the Indian firms' point of view, it is easier to export than to undertake direct investments. Export activity does not involve huge investment, nor is it risky. Lately, as just discussed, African countries are trying to improve their drug registration and regulatory systems, but traditionally it has been very easy to enter most of the African markets.

The most common model followed by Indian firms is for the Indian exporters to tie up with local importers/distributors. In some African countries, this trade is dominated by people of Indian origin, so that linking up with traders is not a difficult proposition in these countries. Again in comparison to China, the main competitor in Africa, India has the advantage of more exposure to the English language, which is understood and used in many African countries. The main role of the Indian company is therefore restricted to getting the product registered and manufacturing and supplying to local partners. This hardly requires much investment: Indian companies do not create separate plants for the African markets. They use their existing capacity - often excess capacity - for the purposes. It is also practically riskless. Many exporters insist on advance payment. Even where the medicines are supplied on credit, at worst the Indian company will lose money for that consignment, and then they can stop supplying medicines in the future.

Investments abroad, on the other hand, involve more risks. It is very important for foreign investors to be assured of the safety of their investments. Africa is now politically much more stable. But foreign investors seem to expect some proactive steps on the part of the government to instill confidence that their money will be safe and that, if necessary, they can take money out of the country. There are also risks related to volatility of foreign exchange rates. Perhaps most important, the local partnerships required for direct investments carry higher risks. Export activities of Indian companies are carried out through local partners, as mentioned above, and in such cases the roles are clearly defined and risks are fewer. In case of joint ventures, however, the success of the company will depend much more on the local partners. The question of reliability of partners becomes more important in the case of investments abroad, 
since substantial investments would be involved and it is not easy to get rid of undesirable partners.

It follows that it is still quite a challenge to undertake manufacturing activities in Africa. Most of these countries suffer from various disadvantages, discussed in the preceding chapters. They include lack of technical know-how and trained manpower in the local African labour markets and the low levels of development of support industries including suppliers of APIs, other materials and machinery. Production costs may be higher than in India because input costs and utility costs are higher, and also because productivity may be lower. In some smaller countries, the market is considered too small for profitable operations. ${ }^{5}$ It is therefore much easier for Indian companies to manufacture in India and then to serve the African markets through exports.

This current status and set of perceptions can however be changed through policy interventions. Left to themselves, foreign firms may not be keen to invest. But if proper conditions are created, if the abovementioned issues and factors are taken care of, then they might be induced to do so. If the experience of other countries is any guide, then neither the inflows of FDI nor the benefits from FDI result from a passive open-door FDI policy (Lall and Narula, 2004; Chang, 2004). What is required is an active industrial policy.

The last section of this chapter develops this argument for the case of Ghana. ${ }^{6}$ It discusses how foreign firms can help to develop a local pharmaceutical industry, and how they can be induced to contribute to promote local production.

\section{Ghana, industrial policy and foreign direct investment}

Ghana is a relatively small African country. The size of its total formulations market was estimated at about US\$329 million in 2012 (BMI, 2013: 16). There are about 38 pharmaceutical manufacturing units in Ghana of which about 20 are actively involved in manufacturing formulations. Only one company, LaGray, started manufacturing an API (erythromycin) for their own use in formulation manufacturing. Local production caters to about $30 \%$ of the market, with the remaining $70 \%$ of demand being met from imports. Some of the local firms, for example Kama and Ernest Chemists, are involved in both manufacturing and importing.

India is a major source of Ghanaian imports not only of formulations but also of the APIs and other materials required for the local production of formulations. Out of the $30 \%$ of the market which is supplied by local 
manufacturers, 25\% are over-the-counter (OTC) medications and the remaining 5\% are simple prescription formulations. About two-thirds of drug purchase in Ghana are financed through out-of-pocket expenditure, the remaining being financed through public procurement, donorfunded purchases and reimbursement by the National Health Insurance scheme. Ghana has an elaborate drug distribution system dominated by importers/distributors/wholesalers. The branded generics segment of the market is large, and both imported products and locally manufactured generic products are sold as brands. Local manufacturers are actively involved in sales promotion, particularly for OTC items.

The Ghanaian government has put in place a number of policies that have helped the local industry to grow to attain its present status. Among these policies, one of the most important steps taken to promote the pharmaceutical industry was to ban the imports of finished formulations of 14 widely used products including ampicillin, tetracycline, chlordiazepoxide, indomethacin, paracetamol, aspirin and diazepam. Domestic formulations manufacturing has also benefitted substantially from the industrial protection provided by combination of zero import duties on materials and machinery required for formulations production with $10 \%$ import duty on imports of finished formulations. Another important advantage that domestic formulations manufacturers have been enjoying was the refunding of the 15\% VAT imposed on all materials and machinery required for formulations production. However, in 2013, the government has withdrawn this benefit, as has also happened elsewhere (see Chapter 2).

Like other countries discussed in this book, Ghana also offers a 15\% price preference for domestic suppliers in public procurement. This has also helped manufacturers, though the system has not always functioned properly. Local manufacturers complain that the procurement system is not very transparent, and especially when the government buys at regional and local levels there is suspicion that the $15 \%$ advantage is often not provided. The government does not reveal the prices at which it actually procures. Perhaps if such information is made public the situation will improve.

\section{Industrial policy in Ghana}

What can be done to further increase the share of local production in the Ghanaian domestic market? What is fundamentally important for promoting an industry is to put in place policies to provide access to three key aspects of business activity: finance, technology and markets. 
This section first discusses the problems of finance and technology in the context of Ghana. It then explores the ways in which a policy of ensuring a larger market for local producers can prompt FDI to assist the development of the pharmaceutical industry in Africa.

Under the conditions in which they operate, the local firms hardly earn adequate profits to plough back into investments. Furthermore, the rate of interest charged by banks in Ghana is exorbitant, often exceeding $30 \%$ per annum. As shown below, to set up Good Manufacturing Practice (GMP)-compliant manufacturing plants, to develop products for getting regulatory approval and for marketing these products, huge funds are required. Taking loans at such high interest rates is simply not a viable option, so that exploring other funding options is vital. The more resourceful foreign firms with access to diverse sources of funding offer one of the possible policy options.

Technology, furthermore, is a fundamental constraint in Africa today. When pharmaceutical manufacturing started in Ghana, technical requirements were simpler and technology was often arranged through informal channels. The promoters of local companies such as Amponsah Efah, LaGray and Pharmanova are themselves technologists, and they have used their knowledge and contacts to set up small-scale plants. But the technological scenario in recent years has changed fundamentally. Current requirements are significantly tougher. If local manufacturing in Ghana is to make a significant difference to the industry, then technical knowledge and expertise need to be available qualitatively and quantitatively on a big scale.

The first technological requirement is that the manufacturing plants need to be GMP compliant. To set up a GMP-compliant plant, significant additional costs, particularly investment costs, have to be incurred. Moreover, the products manufactured need to be approved for marketing by the local drug control administration. The companies are required to undertake various types of studies (e.g. bioequivalence studies) and to generate data and submit dossiers to the drug control authorities. Marketing approval is granted after various types of review by the latter, including chemistry review, bioequivalence review and after-plant inspection.

The technical knowledge required to set up and run GMP-compliant plants and to develop products for getting regulatory approvals for marketing are not widely available in Ghana and other African countries. It is vitally important to arrange this if the local industry is to develop. 
A possible solution is to use the technological resources of foreign firms for the purpose. Manufacturing operations by Western MNCs are carried out in quite a different environment, while the situation in India is much closer to that in Africa. Pharmaceutical technical knowledge is furthermore highly diffused in India, so if Indian companies invest in Africa, then a major constraint will be lifted.

Furthermore, as Chapter 5 has emphasized, market access and serving the local market effectively are essential elements of business success. If the African governments can initiate policies to substantially limit the access of foreign firms to the domestic market, then Indian (or other foreign) companies will lose out unless they undertake investments in Africa to cater to that market. Where the loss is substantial, as in the cases of larger countries or regional markets, chances of FDI will be much higher. How can a country manage its domestic market to induce foreign firms to invest?

Policy makers in developing countries often are reluctant to impose import controls on the grounds that such an action may lead to shortages and/or lack of import competition may lead to higher prices. But this need not necessarily be the case, as Ghana shows. The products on its banned list are manufactured adequately in the country, and the country did not suffer from shortages after the policy was imposed. Lack of import competition has not resulted in higher prices. Importantly, import competition has been replaced by domestic competition, leading to competitive prices in the domestic market.

To explore the question of pricing further, Table 6.4 compares the retail prices of selected products in India and Ghana. The products include some of those which are manufactured in Ghana, for example ciprofloxacin, paracetamol, amlodipine, diazepam, metformin and also some of those that are not currently manufactured in Ghana, for example anastrazole, granisetron, losartan, rabeprazole and rosuvastatin. As Table 6.4 shows, the extent of price differentials between India and Ghana is quite different, depending on whether these products are manufactured in Ghana or not. For the products not manufactured in Ghana, the price differentials are significantly larger. For the products manufactured in Ghana, not only is the price differential much narrower - less than 1.5 times - but it is in fact the case that for three products, Ghanaian prices are lower than those in India. These include diazepam and paracetamol, which are products reserved for local manufacturers. Thus Table 6.4 suggests that local production in Ghana has contributed to affordability. 
Table 6.4 Comparison of retail formulations prices in India and Ghana

$\begin{array}{ccc}\text { India: Median } & \text { Ghana: Median } & \text { Ghana/India } \\ \text { price in INR } & \text { price in INR } & \text { price ratio: } \\ \text { (1 tablet) } 2013 & (1 \text { tablet) } 2011 & \text { Col(3)/col(2) }\end{array}$

Tablets manufactured in Ghana

$\begin{array}{llll}\text { 1. Ciprofloxacin, } 500 \mathrm{mg} & 6.18 & 9.11 & 1.5 \\ \text { 2. Amlodipine, } 5 \mathrm{mg} & 2.36 & 3.64 & 1.5 \\ \text { 3. Metformin, } 500 \mathrm{mg} & 1.46 & 1.52 & 1.0 \\ \text { 4. Diazepam, } 5 \mathrm{mg} & 2.90 & 0.30 & 0.1 \\ \text { 5. Paracetamol, } 500 \mathrm{mg} & 1.14 & 0.30 & 0.3 \\ \text { 6. Diclofenac, } 50 \mathrm{mg} & 1.43 & 1.82 & 1.3 \\ \text { 7. Lisinopril, } 5 \mathrm{mg} & 4.58 & 6.07 & 1.3 \\ \text { 8. Atorvastatin, } 10 \mathrm{mg} & 8.60 & 9.11 & 1.1 \\ \text { 9. Cetirizine Hcl, } 10 \mathrm{mg} & 3.10 & 3.04 & 1.0 \\ \text { 10. Metronidazole, } 200 \mathrm{mg} & 0.39 & 0.61 & 1.6\end{array}$

Tablets not yet manufactured in Ghana

$\begin{array}{lrrr}\text { 1. Anastrazole, } 1 \mathrm{mg} & 48.50 & 182.10 & 3.8 \\ \text { 2. Cepacitabine, } 500 \mathrm{mg} & 150.05 & 267.08 & 1.8 \\ \text { 3. Granisetron, } 1 \mathrm{mg} & 14.05 & 409.73 & 29.2 \\ \text { 4. Itraconazole, } 100 \mathrm{mg} & 47.50 & 182.10 & 3.8 \\ \text { 5. Losartan, } 50 \mathrm{mg} & 5.65 & 12.14 & 2.1 \\ \text { 6. Rabeprazole, } 20 \mathrm{mg} & 2.75 & 75.88 & 27.6 \\ \text { 7. Risperidone, } 2 \mathrm{mg} & 3.80 & 75.88 & 20.0 \\ \text { 8. Rosuvastatin, } 20 \mathrm{mg} & 20.36 & 69.81 & 3.4 \\ \text { 9. Tindazole, } 500 \mathrm{mg} & 5.52 & 69.81 & 12.7 \\ \text { 10. Sertraline, } 100 \mathrm{mg} & 6.3 & 98.64 & 15.7\end{array}$

Sources: 1. For Indian prices in col (2): median prices of retail brands accounting for $1 \%$ or more of the market. Market share data have been obtained from the Sales audit data of AIOCD Pharmasofttech AWACS Pvt. Ltd (AIOCD-AWACS), a pharmaceutical market research company; Price data have been obtained from CIMS (2013).

2. For Ghana prices in col (3): 'Medicines List', February 2011 of the Ghana National Health Insurance Scheme (http://www.nhis.gov.gh/_Uploads/dbsAttachedFiles/1(3).pdf). Prices in Ghana cedis (GHC) have been converted to Indian rupee (INR) using the annual average exchange rates for 2011 from www.oanda.com. The list specifies the maximum prices at which the medicines purchased at the retail level are reimbursable. Pricing data are collected from manufacturers, wholesale distributors, private pharmacies, government, mission and private health facilities and the median prices are set as the maximum price reimbursable under the insurance scheme.

3. Since the Ghana prices refer to 2011 whereas the Indian prices refer to 2013, depending on the extent to which Ghana prices have gone up since 2011, the price differential in fact may be larger than the figures show.

If the number of products on the banned list is increased, and if free flow of imports into the economy is controlled, then not only will domestic producers find a larger market. Import restrictions may also induce foreign firms exporting to the country to undertake manufacturing within the country. 
Imports can also be controlled in several other ways. Ghana has introduced a National Health Insurance Scheme (NHIS), which covers about half the population. About $40 \%$ of the funds paid out by health insurance are for medicines. The NHIS-funded formulations market has therefore emerged as a major market segment in Ghana accounting for about 23\% of the market (Seiter and Gyansa-Lutterodt, 2009: 19). The NHIS has expanded since that 2009 study, and the share of insurancefunded medicine purchase has risen. The substantial bargaining power of the NHIS agency can thus be used to enlarge the domestic market. The NHIS does not currently differentiate in its procurement between medicines according to whether they are manufactured locally or imported. However, after allowing some time for capacities to develop, NHIS reimbursement could be restricted to locally manufactured products. Since the prices to be reimbursed are being fixed by NHIS in any case, the possibility of such actions leading to higher prices will not arise.

A further policy option available is to use the instrument of government procurement. So far as the institutional market is concerned, the only benefit the local manufacturers receive is the $15 \%$ price preference, and that too, as noted above, does not operate properly. An important flexibility that the World Trade Organization (WTO) provides concerns public procurement. The WTO Agreement on Government Procurement (GPA) is a plurilateral agreement which is applicable only to the member countries which have signed the GPA. African countries, including Ghana, have not yet joined the GPA. ${ }^{7}$

Public procurement of drugs (and other goods) in Ghana is currently guided by the provisions of the Public Procurement Act. This provides for three types of competitive tendering: international, national and restricted. 'International tendering' means that organizations responding need not necessarily be located in Ghana. 'National tendering' means that the tendering can be restricted to organizations located in Ghana, but the organizations need not be manufacturers. They can be importers located in Ghana.

A simple step that could be initiated in Ghana for the further development of the pharmaceutical industry is to introduce tendering restricted to local manufacturers. This might be a two-stage tendering process: a technical evaluation and then evaluation of the financial bid. At the first stage of technical evaluation, tenders may be accepted only from those local manufacturers that are GMP-compliant and that have the manufacturing capacities to satisfy the procurement requirements. The financial bid may be restricted to the companies which qualify in the technical evaluation. Based on the widely used International Reference Prices, ${ }^{8}$ maximum purchase prices may be also specified. This 
will ensure a larger domestic market for local manufacturers, and hence a more attractive market for FDI, without compromising on prices.

\section{Conclusion}

This chapter can be appropriately concluded with a quotation from the Chairman of an Indian company currently exporting pharmaceuticals to Africa. He summarized the prospects of FDI in Africa. He told us during an interview that if imported products including those from India are freely available in Africa, then it is difficult to induce Indian companies to go to Africa and set up plants. But if local production is somewhat protected, and if this is supplemented with few steps to take care of the disadvantages of local production in Africa including some incentives, for example some income tax benefits particularly in initial years and infrastructure support (land, water, roads, electricity), then the prospects of FDI from India will be brighter. In fact, his company will be willing to explore the possibility actively.

\section{Notes}

Acknowledgements: In writing this paper, the author has used the results of interviews carried out in India, Ghana and Tanzania in connection with other studies including those funded by ESRC (UK), UNIDO and UNDP. The author benefitted immensely from the comments and suggestions from Maureen Mackintosh. The author would also like to thank Alastair West, Juergen Reinhardt and Cecilia Oh for discussions and Geoffrey Banda and Watu Wamae for comments.

1. Wasem Noor, 'Pharm Exec's Pharma 50 2014', 9 June 2014 (accessed 17 April 2014 from http://www.pharmexec.com/pharm-execs-pharma-502014?id=\&sk=\&date=\&\&pageID=2); BMI Espison, 2013.

2. See note 1 above.

3. For example, after the expiry of the basic patent for a chemical, generics companies that can successfully challenge some of the secondary patents can prevent other generic companies from entering the market for a limited period of time, gaining substantial additional value-added.

4. Source: as in Table 6.3.

5. See Guimer et al. (2004); Kaplan and Laing (2005); Losse et al. (2007); Chaudhuri et al. (2010); Abbott (2011); Moon (2011); UNCTAD (2011); African Union and UNIDO (2012); Chaudhuri and West (2014) for further insights into local production in Africa.

6. The case study on Ghana relies to a great extent on the information collected through interviews while doing studies for UNIDO, Vienna and UNDP, New York.

7. Mostly developed countries are currently members of GPA; for the list of those who have joined, see https://www.wto.org/english/tratop_e/gproc_e/ memobs_e.htm 
8. Management Sciences for Health (MSH), International Drug Price Indicator Guide (annual) http://apps.who.int/medicinedocs/documents/s19968en/s19968en. pdf, accessed 20 April 2015.

Except where otherwise noted, this work is licensed under a Creative Commons Attribution 4.0 Unported License. To view a copy of this license, visit https://creativecommons.org/version4 